\title{
Different tray cell volumes for lettuce grown in conventional and hydroponic system
}

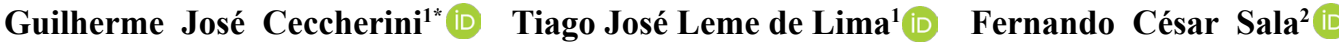

${ }^{1}$ Centro de Ciência Agrárias (CCA), Universidade Federal de São Carlos (UFSCar), 13600970, Araras, SP, Brasil. E-mail: gui.ceccherini@hotmail.com. ${ }^{*}$ Corresponding author.

${ }^{2}$ Departamento de Biotecnologia, Produção Vegetal e Animal (DBPVA), Centro de Ciências Agrárias, Universidade Federal de São Carlos (UFSCar), Araras, SP, Brasil.

ABSTRACT: Nowadays, an important economic movement is involved in the improvement of polyethylene trays for the production of seedlings, being developed with different volumes, numbers and cell formats in an each culture-specific manner. The objective of the present study was to evaluate the performance of curly lettuce originated from seedlings from trays with different volumes, through the

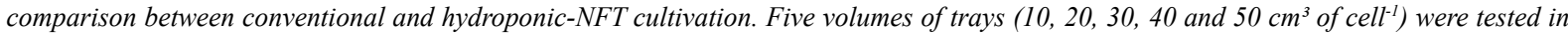
conventional and hydroponic cultivation, from February to March 2016. For the purpose of comparison, the plants were evaluated through the characteristics of height, circumference, stem diameter, number of leaves, fresh shoot mass and productivity. The use of volumes greater than $10 \mathrm{~cm}^{3}$ showed higher precocity in both cultivation systems, with hydroponic cultivation being more precocious and productive when compared to conventional cultivation.

Key words: Lactuca sativa L., seedling, comparative, field, hydroponic.

Diferentes volumes de célula da bandeja para alface cultivada em sistema convencional e hidropônico

RESUMO: Atualmente, um importante movimento econômico está envolvido na aprimoração das bandejas de polietileno para a produção de mudas, sendo desenvolvido com diferentes volumes, números e formatos de células de forma específica para cada cultura. O objetivo do presente estudo foi avaliar o desempenho de alface crespa, oriunda de mudas de bandejas com diferentes volumes, através da comparação entre cultivo convencional e hidropônico-NFT. Cinco volumes de bandejas (10, 20, 30, 40 e $50 \mathrm{~cm}^{3}$ de célula $\left.{ }^{-1}\right)$ foram testados em cultivo convencional e hidropônico, no periodo de fevereiro a março de 2016. Para fins de comparação, as plantas foram avaliadas através das características de altura, circunferência, diâmetro do caule, número de folhas, massa fresca da parte aérea e produtividade. O uso de volumes superiores a $10 \mathrm{~cm}^{3}$ apresentou maior precocidade em ambos os sistemas de cultivo, sendo o cultivo hidropônico mais precoce e produtivo quando comparado ao cultivo convencional.

Palavras-chave: Lactuca sativa L., mudas, comparativo, campo, hidroponia.

\section{INTRODUCTION}

Lettuce (Lactuca sativa L.) is the most important leafy vegetable in terms of production area in conventional cultivation and represents $80 \%$ of the hydroponic-NFT cultivation in Brazil (FURLANI, 1999; SALA \& COSTA, 2012). Having generated under wholesale trading in 2016, a higher amount in $\mathrm{R} \$ 288$ million and production of 105.207 tons (CONAB, 2017), it is still estimated that in retail has reached $\mathrm{R} \$ 8$ billion and production of more than 1.5 million tons (ABCSEM, 2017).

In Brazil in recent years, more and more vegetable producers have been interested in the adoption of higher technologies in their cultivation system, being a good example of this option, the cultivation in hydroponics-NFT. This technology of soilless cultivation represents a more sustainable alternative to conventional cultivation, since it improves nutrition, water use and phytosanitary control of the plants, allowing the producer to obtain precocity in the cycle, greater productivity per area with higher quality and cleaning of product, besides reducing the manpower due better ergometry in handling (NETO \& BARRETO, 2011; PAULUS et al., 2012). Representing in this way, in a very interesting alternative of cultivation for the producers, mainly of the familiar agriculture, since, besides being able to 
be considered like a more sustainable technological investment, generates a good and fast rate of return the initial investment of implantation.

Polyethylene trays are being developed with different volumes for substrate and cell format, in order to establish which new volume and format is better suited in a specific way, to every type of olericultural species (MINAMI, 2010). Where, in practice, nurserymen have used standard trays of 200 cells to produce lettuce seedlings, because they have lower volumes of substrate by cells, providing lower production costs due to less substrate use and more seedlings per square meter.

However, this economy in the stage of production of the seedlings can cause less development and quality of the same, reflecting in lower field potential after transplantation, resulting in losses in production, cycle extension and malformation of plants, because the lower volume of substrate available for root development causes greater competition for water, nutrients and oxygen due to the limitation in the pore space due to the presence of larger root mass. Thus, when transplanted, the seedlings are unable to compensate for evapotranspiration, even if well irrigated (WIEN, 1997; REGHIN et al., 2007).

Faced this new trend in the development of trays with higher volumes of substrate per cell for seedling formation and the growing interest in the adoption of hydroponic-NFT by the producers, the present research had as objective to elucidate how the use of greater volume of tray can influence in the precocity production of curly lettuce, comparing its performance of cultivation in conventional system with hydroponics.

\section{MATERIALS AND METHODS}

The experiment was conducted in the experimental field of Horticulture of the University Federal of São Carlos (UFSCar), in Araras-SP campus, in 2016 ( $22^{\circ} 21^{\prime} 25^{\prime \prime}$ "south latitude, $47^{\circ} 23^{\prime} 03^{\prime \prime}$ west longitude and altitude $646 \mathrm{~m}$ ). The climate of the region, according to the classification of Köppen, is designated as a Cwa (humid subtropical climate), with average temperatures of $20.3{ }^{\circ} \mathrm{C}$ and average annual precipitation of $1.312 \mathrm{~mm}$. To carry out the experiment, in January the seeds were sown in the trays, and when they were ready in February, the seedlings were transplanted and harvest in March for evaluation.

The experimental design was a randomized block (DBC), forming a factorial scheme in $5 \times 2$, with five tray volumes $\left(10,20,30,40\right.$ and $50 \mathrm{~cm}^{3}$ of cell $^{-1}$ ) and two cultivation methods (hydroponic and soil) with 4 replications for both cultivation, composed of field plots with 24 and hydroponics with 45 plants. From the field, four plants were collected at random and eight plants from the hydroponics of the central lines, avoiding the external lines of the borders, for subsequent analysis of the agronomic characteristics of plant height $(\mathrm{H} \mathrm{cm})$; circumference $(\mathrm{C} \mathrm{cm})$; diameter of stem (DC mm); number of leaves (NF) with a minimum of $5 \mathrm{~cm}$; fresh shoot mass (MFA g) and Productivity (Prod t ha' ${ }^{-1}$ ).

The seedlings production was carried out by the nursery of vegetable seedlings (IBS Mudas), located in the county of Piracicaba-SP, between January and February 2016 (22³7’46

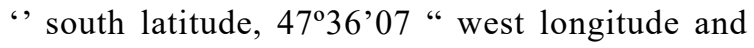
altitude $547 \mathrm{~m}$ ).

For sowing, a pelleted seed per cell was used in the 5 different trays (Table 1) of the cultivar 'Vanda' $\left(\right.$ Sakata $\left.^{\circledR}\right)$. The substrate used for sowing was type fine-textured coconut fiber (Amafriba ${ }^{\circledR}$ ).

After sowing, the trays were kept in a germination room under $80 \%$ relative humidity and $25{ }^{\circ} \mathrm{C}$ for 48 hours. Soon after, they were placed in benches with a height of $0.50 \mathrm{~m}$, in an oven with arch structure, $100 \mathrm{~m}$ long, $10 \mathrm{~m}$ wide and $4 \mathrm{~m}$ right foot. The side and front walls were of anti-aphid screen, with $150 \mu \mathrm{m}$ polyethylene plastic cover and concrete floor. Irrigation and fertigation were by sprinkler on spray boom system, until the final formation of the seedlings for 30 days.

For the transplanting of the seedlings in the field, the soil was prepared with light grating, followed by the harrow for lifting the beds with a height of 30 $\mathrm{cm}$ and divided into plots of $2 \mathrm{~m}^{2}$. The pre-planting fertilization was performed with fertilizer 4-14-8 (1.2 $\mathrm{t} /$ ha of fertilizer), sprinkler irrigation with shift regulated to provide water blade of approximately $8 \mathrm{~mm}^{\text {day }}{ }^{-1}$ and weed control by hand, per weeding. Posteriorly, the transplant was performed with spacing of $0.3 \mathrm{~m} \mathrm{x}$ $0.25 \mathrm{~m}$. The cover fertilizer was made with Calcium Nitrate $\left(0.3 \mathrm{t} / \mathrm{ha}^{-1}\right)$ and Potassium Chloride $\left(0.12 \mathrm{t} / \mathrm{ha}^{-1}\right)$ at 12 days after transplanting.

For transplantation in the NFT system, the nursery phase corresponded to a motor pump and reservoir with a capacity of $500 \mathrm{~L}$, profiles of $35 \mathrm{~mm}$ ( $5 \mathrm{~cm}$ high and $7 \mathrm{~cm}$ wide), with spacing of $0.10 \mathrm{~m}$ between plants and $0.15 \mathrm{~m}$ between profiles, with a width of $15 \mathrm{~m}$, slope of $6 \%$, red screen cover $30 \%$ and side walls of red screen with length of $40 \mathrm{~m}$, width of $48 \mathrm{~m}$ and $1.95 \mathrm{~m}$ right foot. The structure of the definitive phase had a one self-priming water pump (1 hp engine, maximum flow of $3600 \mathrm{~L} \mathrm{hour}^{-1}$ ), reservoir with a capacity of $5000 \mathrm{~L}$, screen cover and side walls 
Table 1 - Tray specific features. UFSCar (CCA), Araras, SP, 2016.

\begin{tabular}{lccccc}
\hline Number of cells & Volume $\left(\mathrm{cm}^{3}\right)$ & Profundity $(\mathrm{cm})$ & Área $\left(\mathrm{cm}^{2}\right)$ & Superior cell format & Inferior cell format \\
\hline 72 & 50 & 6 & 13.78 & Circle & Conic \\
64 & 40 & 5 & 22.78 & Quadrate & Cube \\
98 & 30 & 5.5 & 13.52 & Quadrate & Triangular conical \\
128 & 20 & 4.5 & 13.52 & Quadrate & Triangular conical \\
200 & 10 & 4 & 13.52 & Quadrate & Triangular conical \\
\hline
\end{tabular}

equal to the nursery phase, four benches containing seven $75 \mathrm{~mm}(7.5 \mathrm{~cm}$ high and $10 \mathrm{~cm}$ width $)$ profiles with $15 \mathrm{~m}$ length and $0.30 \mathrm{~m}$ spacing between profiles and $0.25 \mathrm{~m}$ between plants and $6 \%$ of the benches.

The flow of the nutrient solution in the system was adjusted to $0.5 \mathrm{~L} \mathrm{~min}^{-1}$ in the nursery profile and in the definitive to $1.8 \mathrm{~L} \mathrm{~min}^{-1}$ per profile. To formulate the nutrient solution, it was prepared the formulated by FURLANI (1999), with the circulation scheme of the solution nutrition regulated every 15 in 15 minutes during the day (06:00 to 18:00) and 15 minutes to every 4 hours during the night time. Electrical conductivity and $\mathrm{pH}$ of the nutrient solution were controlled and maintained daily from 1.2 to 1.7 and 5.5 to 6.5 , respectively, since transplant until harvest.

Then, the seedlings formed in the 20,30 , 40 and $50 \mathrm{~cm}^{3}$ volumes per cell were transplanted directly to the definitive profiles, as they had adequate sizes to not slip for inside the profiles. While the seedlings formed in the cells of $10 \mathrm{~cm}^{3}$ had to stay 10 days before in the nursery phase until reach size suitable for transplantation to the final phase.

For evaluation, the lettuces were conducted until 30 days after transplantation in both cultivations. However, the lettuces of the hydroponics were evaluated 10 days before the field, because they were transplanted 10 days before.

In the analysis of the data, the statistical software "Sisvar 5.6" was used and the Tukey test was applied, at $5 \%$ probability. Then, the data were included in scatter plots and applied to the regression lines by the MICROSOFT EXCEL $2010^{\circledR}$ software.

\section{RESULTS AND DISCUSSION}

At harvest, the 200-cell tray seedlings generated lettuce with a circumference of $81 \mathrm{~cm}$ in the field and $94.12 \mathrm{~cm}$ in hydroponics (Figure 1A), indicating precocity as a function of the cultivation way. That observation is reinforced by FELTRIM et al. al. (2005) with american lettuce and STEINER et al.
(2009) with crisp lettuce, where the authors reported precocity in the cycle in relation to conventional cultivation, this is because the direct contact of the roots with the nutrient solution, allowed a more efficient nutrition without losses, such as leaching (NETO \& BARRETO, 2011). This difference was more evident when we verified that the volume of 10 $\mathrm{cm}^{3}$ in hydroponic was superior to all the volumes in the field, except for the one of $50 \mathrm{~cm}^{3}$ that acquired average circumference of $100,31 \mathrm{~cm}$; however, the volume that gave greater circumference was the of 40 $\mathrm{cm}^{3}$ in hydroponics with $116.65 \mathrm{~cm}$. The higher cell volume for substrate gives a more vigorous seedling, allowing lettuce to reach the harvest point early, due to the greater field potential (REGHIN, et al., 2007; COCCO et al., 2015). Agreeing with the results of $\mathrm{COCCO}$ et al. (2015) with strawberry (Fragaria $\mathrm{x}$ ananassa Duch.) and MACHADO et al. (2018) with tomato (Solanum lycopersicum L.), the use of seedlings with greater volume of tray is advantageous for the producer, because has greater space for the development of a denser root system, implying in a greater surface of absorption of water and nutrients, promoting better adaptability to the field, generating precocity in the cultivation (REGHIN et al.,2007; LEAL et al.,2011; COCCO et al.,2015).

According to FLÔRES et al. (2016), lettuces with smaller circumference generate a smaller number of leaves; however, the volume of $50 \mathrm{~cm}^{3}$ in the field exhibited a larger circumference than the $10 \mathrm{~cm}^{3}$ in hydroponics (Figure 1A), but obtained 1.25 plant $^{-1}$ leaves less (Figure 1B), noting influence of the best nutrition of the production system. With the standard volume of $10 \mathrm{~cm}^{3}$ in the field (14.81 leaves plant $^{-1}$ ) as a comparative parameter, we reported that the $50 \mathrm{~cm}^{3}$ in the field presented greater differential gain of leaves number with 7.5 plant $^{-1}$ leaves more, and in relation to $10 \mathrm{~cm}^{3}$ in hydroponics, this difference reached 8.76 plant $^{-1}$ leaves $(59.08 \%$ more). In addition, the volume of $40 \mathrm{~cm}^{3}$ in hydroponics was the one that presented the highest number of leaves 


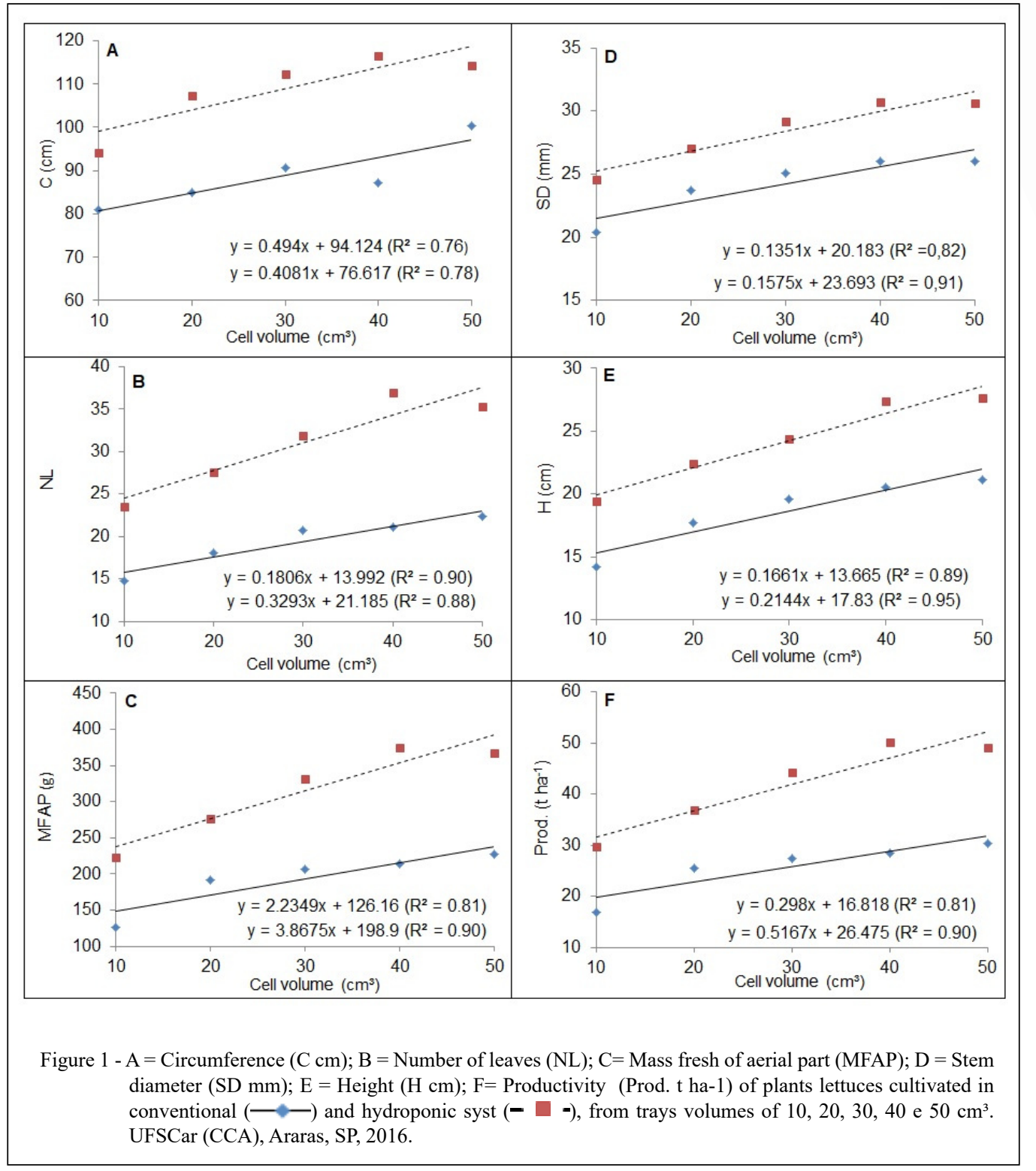

(36.96 leaves plant $^{-1}$ ), between the volumes and cultivations. This increase in the number of leaves due to the larger tray volume, as which has also described by LEAL et al. (2011) in lettuce and LUZ et al. (2018) in arugula (Eruca sativa M.). This higher number of leaves generated by the higher volume and cultivation in hydroponics is favorable, because it promotes greater interception of light energy that will be converted into chemistry and will serve to boost the development of the plants more vigorously, causing precocity in the harvest (TAIZ et al., 2017)

As a result of the increase in the circumference and number of leaves, was verified increase in the weight of fresh mass, according the increase of volume. When used as a parameter comparative, the volume of $10 \mathrm{~cm}^{3}$ in the field presented an average of $127 \mathrm{~g} \mathrm{plant}^{-1}$, different from the volume of $50 \mathrm{~cm}^{3}$ that obtained the greatest highest in the field with 227.56 g plant $^{-1}(79.18 \%$ more) (Figure $1 \mathrm{C}$ ). This influence of volume on the fresh mass was also reported in tomato (Solanum lycopersicum L.) (RODRIGUES et al., 2010), basil (Ocimum basilicum L.) (MAGGIONI et al., 2014) and lettuce (ORTIZ et al., 2015). In addition to this, the cultivation system also influenced the weight gain, because while the soil cultivation had showed a maximum of $227.56 \mathrm{~g} \mathrm{plant}^{-1}$, in hydroponics the maximum weight obtained was $375.25 \mathrm{~g} \mathrm{plant}^{-1}$ (64.90\% more) (Figure 1C), corroborating with described by STEINER et al. (2009). 
The volumes of 40 and $50 \mathrm{~cm}^{3}$ presented similar values $(26 \mathrm{~mm})$ in the field for characteristic stem diameter, being thicker at $5.63 \mathrm{~mm}$ than $10 \mathrm{~cm}^{3}$ (Figure D), also in the field too. And in hydroponics, the volume of $40 \mathrm{~cm}^{3}$ presented stem diameter higher in $6.12 \mathrm{~mm}$ in relation to $10 \mathrm{~cm}^{3}$ and was superior to the others for result in plants with stem diameter in $30.71 \mathrm{~mm}$. This characteristic can be exploited by nurseries at the time of commercialization, because; although, the greater use of substrate for the production of seedlings, he will be offering seedlings with greater vigor and; consequently, a higher price. In this way, farmers can obtain a better uniform, early and lower loss of plantation, since the larger seedlings are larger in stem diameter, thus tolerating mechanical stresses and adverse environmental conditions after transplantation (SCHWERTNER et al., 2013), assuring the producer to offer more lettuces. Thereby indicating a possible cost-benefit relationship in the production chain, but it is necessary to carry out a better economic approach.

Using the $10 \mathrm{~cm}^{3}$ volume of the field as a parameter, we observed at the harvesting point, the lettuces showed a height of $14.25 \mathrm{~cm}$ (Figure $1 \mathrm{E}$ ), being smaller in $7.55 \mathrm{~cm}$ for the one of $50 \mathrm{~cm}^{3}$ in field and $5.21 \mathrm{~cm}$ smaller than the $10 \mathrm{~cm}^{3}$ in hydroponics, demonstrating greater development and precocity due to the higher volume of cell for substrate and choice of the culture system, because it allowed the lettuces to reach the harvest point quickly. And associated to the hydroponic cultivation makes this precocity more evident, since in the present study the volumes of $40 \mathrm{~cm}^{3}$ and $50 \mathrm{~cm}^{3}$ reached a height of $27.40 \mathrm{~cm}$ and $27.68 \mathrm{~cm}$. This happen because the higher cell volume for substrate assures a greater supply of water and nutrients to the root system and due the better nutrition of the plants and effective absorption of nutrients the direct contact of nutritive solution with the root system confers in hydroponic, causing greater development and precocity in the cycle (REGHIN et al., 2007; NETO \& BARRETO, 2011). In addition, for being marketed in boxes, how much larger the lettuce size will be necessary smaller number of plants to compose the box and; consequently, the return per area will be higher to the producer.

Among the volumes and systems tested, the volume of $10 \mathrm{~cm}^{3}$ in the field presented the lowest yield stipulated with $16.93 \mathrm{t} \mathrm{ha}^{-1}$, a value close to the national lettuce production in the year of 2017 that reached $18.6 \mathrm{tha}^{-1}$, according to data from the Brazilian Confederation of Agriculture and Livestock (CNA, 2017), while the highest stipulated productivity was registered with the volume of $40 \mathrm{~cm}^{3}$ in hydroponics, with $50.03 \mathrm{t} \mathrm{ha}^{-1}$ (Figure 1F). For farmers who always searched the maximum yield, it is viable invest in the purchase of seedlings in trays with higher volumes, since the high productivity obtained results in more boxes per area, justifing their recommendation. In addition, the higher productivity obtained in hydroponics is mainly due the direct availability of nutrients in the rhizosphere region, which favors the rapid and efficient absorption of nutrients, allowing the species or variety to reach its maximum genetic potential (NETO \& BARRETO, 2011; RANAWADE et al., 2017), as already described in the literature on lettuce (STEINER et al., 2009) and spinach (Spinacia oleraceae) (RANAWADE et al., 2017). Thus, with the high productivity in a smaller area, shorter cycle and better prices of hydroponics, the producer can obtain a good profit and; therefore, a quick return of the initial invested capital (NETO \& BARRETO, 2011).

\section{CONCLUSION}

Plants from seedlings produced in trays larger than $10 \mathrm{~cm}^{3}$ reach the harvesting point early, because the larger volume of available substrate did not oppress the maximum capacity of root development and consequently the aerial part, resulting in larger plants. This enables rapid reuse of space and greater box picking per area because the better vigor of seedlings produced in trays with higher volumes. The evaluated characteristics showed us that the volume of $40 \mathrm{~cm}^{3}$ was more satisfactory in hydroponics, while in the soil it was $50 \mathrm{~cm}^{3}$. The high yield in hydroponics outweighs the investment in adopting the cultivation method.

\section{ACKNOWLEDGEMENTS}

The authors would like to thank IBS Mudas for providing the seedlings and for the support of members of the Grupo de estudos em horticultura (GEHORT). Also in part, thanks the Coordenação de Aperfeiçoamento de Pessoal de Nível Superior (CAPES), Brasil - Finance code 001.

\section{DECLARATION OF CONFLICT OF INTERESTS}

The authors declare no conflict of interest. The founding sponsors had no role in the design of the study; in the collection, analyses, or interpretation of data; in the writing of the manuscript, and in the decision to publish the results.

\section{AUTHORS' CONTRIBUTIONS}

GJC, TJLL and FCS designed and designed experiments. GJC and TJLL performed the experiments. The FCS supervised the experiments. The GJC performed statistical analyzes of experimental data. GJC prepared the draft manuscript. 
All authors critically reviewed the manuscript and approved the final version.

\section{REFERENCES}

ABCSEM-Associação Brasileira do Comércio de Sementes e Mudas. Dados do setor. 2017 Available from: <http://www. abcsem.com.br/dados-do-setor>. Accessed: Jul.16, 2018

CNA- Confederação da Agricultura e Pecuária do Brasil. Mapeamento e qualificação da cadeia produtiva das hortaliças do Brasil. Brasília: CNA, 2017. Available from: <https://www.cnabrasil.org.br/assets/ arquivos/bibliotecas/livro final3 mapeamento e quantificacao da cadeia_de_hortalicas_08.pdf $>$. Accessed: Nov. 2, 2019.

COCCO, C. et al. Growth, development and yield of strawberry from seedlings with different clod volumes. Revista Brasileira de Fruticultura, v.37, n.4. p.961-969, out-dec. 2015. Available from: <http://www.scielo.br/scielo.php?pid=S010029452015000400961\&script $=$ sci_arttext\&tlng $=\mathrm{pt}>$. Accessed: Out. 10, 2018. doi: 10.1590/0100-2945-250/14.

CONAB-Companhia Nacional de Abastecimento. Programa brasileiro de modernização do mercado hortigranjeiro. 2017. Available from: <http://www3.ceasa.gov.br/prohortweb $>$. Accessed: Jul. 16, 2018.

FELTRIM, A. L. et al. Yield of american lettuce cultivated in soil and hydroponic during winter and summer seasons, in Jaboticabal, SP. Revista Brasileira de Engenharia Agrícola e Ambiental, v.9, n.4, p.505-509, out-dez. 2005. Available from: $<$ http://www.scielo.br/scielo.php?script=sci arttext\&pid=S141543662005000400010\&lng=pt\&tlng=pt $>$. Accessed: Aug. 22, 2018. doi: 10.1590/S1415-43662005000400010.

FLÔRES, J.A. et al. Agronomic performance of lettuce cultivars under greenhouse in amazon conditions. Revista de Ciências Agroambientais, v.14, n.2, p.113-116, dez. 2016. Available from: <https://periodicos. unemat.br/index.php/rcaa/article/view/1637>. Accessed: Aug. 18, 2018.

FURLANI, P. R. Hydroponic vegetable production in Brazil. Acta Horticulturae, v.2, n.481, p.777-778, 1999. Available from: $<$ https://www.actahort.org/books/481/481 98.htm>. Accessed: Aug. 17, 2018. doi: 10.17660/ActaHortic.1999.481.98.

LEAL, P.A.M et al. Seedling formation and field production of beetroot and lettuce in Aquidauana, Mato Grosso do Sul, Brazil. Horticultura Brasileira, v.29, n.4, p.465-471, dez. 2011. Available from: $<$ http://www.scielo.br/scielo.php?script $=$ sci arttext\&pid $=$ S0102-05362011000400004\&lng=en\&tlng $=$ en $>$. Accessed: Aug. 19, 2018. doi: 10.1590/S0102-05362011000400004.

LUZ, S.R.O.T et al. Structure of rucches with substrate and type of tray. Enciclopédia Biosfera, v.15, n.27, p.41-47, 2018. Available from: <http://www.conhecer.org.br/enciclop/2018a/agrar/ formacao\%20de\%20mudas.pdf>. Accessed: Jun. 17, 2019.

MACHADO, T. M. et al. Substrate volume in the seedling production influence tomato performance in the field. Revista Terra \& Cultura: Cadernos de Ensino e Pesquisa, v.34, n.esp., p.373-386, set. 2018. Available from: <http://periodicos.unifil.br/ index.php/Revistateste/article/view/512>. Accessed: Jun. 29, 2019.

MAGGIONI, M. S. et al. Development of basil seedlings (Ocimum basilicum L.) in different density and type of substrates and trays. Revista Brasileira de Plantas Medicinais, v.16, n.1, p.10-17, abr. 2014. Available from: <http://www.locus.ufv.br/ bitstream/handle/123456789/18623/artigo.pdf? sequence $=1>$. Accessed: Out. 13, 2018.

MINAMI, K. Produção de mudas de alta qualidade. Piracicaba: Degaspari, 2010, 440p. NETO, E.B.; BARRETO, L.P. The hydroponic techniques. Anais da Academia Pernambucana de Ciência Agronômica, vols. 8 e 9, p.107-137, 2011. Available from: $<$ http://www.journals.ufrpe.br/index.php/apca/article/view/152>. Accessed: Jun. 5, 2019.

ORTIZ, T. A. et al. Agronomic performance of lettuce produced in trays with different cell number field spacings. African Journal Of Agricultural Research, v.10, n.12, p.1407-1411, mar. 2015. Available from: <https://academicjournals.org/journal/AJAR/ article-abstract/E7E53CA51811>. Accessed: Aug. 20, 2018. doi: 10.5897/AJAR2014.9218.

PAULUS, D. et al. Sensory analysis, nitrate and nutriente concentration of lettuce grown in hydroponics under saline water. Horticultura Brasileira, v.30, n.1, p.18-25, jan-mar 2012. Available from: <http://www.scielo.br/pdf/hb/v30n1/ v30n1a04>. Accessed: Jun. 5, 2019. doi: 10.1590/S010205362012000100004 .

RANAWADE, P.S. et al. Comparative cultivation and biochemical analysis of spinacia oleraceae grown in aquaponics, hydroponics and field conditions. International Journal of Current Microbiology And Applied Sciences, v.6, n.4, p.1007-1013, abr. 2017. Available from: <https://www.ijcmas.com/6-4-2017/ P.S.\%20Ranawade,\%20et\%20al.pdf>. Accessed: Aug. 21, 2018. doi: 10.20546/ijcmas.2017.604.124.

REGHIN, M. Y. et al. Endive (Cichorium endivia L.) yield in function of tray types and seedlings age at transplanting. Ciência e Agrotecnologia, v.31, n.3, p.739-747, mai-jun. 2007. Available from: <http://www.scielo.br/pdf/\%0D/cagro/v31n3/a21v31n3.pdf >. Accessed: Aug. 20, 2018.

RODRIGUES, E.T. et al. Production of tomato seedlings in different trays and substrates under greenhouse. Horticultura Brasileira, v. 28, n. 4 p.483 -488 out-dez. 2010 . Available from: $<$ http://www. scielo.br/pdf/hb/v28n4/18.pdf>. Accessed: Oct. 26, 2018.

SALA, F.C.; COSTA, C.P. Retrospective and trends of Brazilian lettuce crop. Horticultura Brasileira, v.30, n.2, p.187-194, abr-jun. 2012. Available from: $<\mathrm{http} / /$ www.scielo.br/scielo.php?script=sci arttext\&pid $=$ S0102-05362012000200002\&lng=pt\&tlng=pt $>$. Accessed: Aug. 20, 2018. doi: S0102-05362012000200002.

SCHWERTNER, D. V. et al. Lettuce productivity and quality of tomato seedlings with potato bioproduct. Ciência Rural, v.43, n.3, p.404-410, mar. 2013. Available from: <http://www.scielo.br/pdf/ cr/v43n3/a7913cr6505.pdf >. Accessed: Oct. 10, 2018.

STEINER, F. et al. Growth and yield of lettuce grown in hydroponic and conventional. Cultivando O Saber, v.2, n.4, p.42-48, out. 2009. Available from: <https://www.fag.edu.br/upload/revista/ cultivando_o_saber/59272b280f9f5.pdf>. Accessed: Aug. 15, 2018.

TAIZ, L. et al. Fisiologia e desenvolvimento vegetal. 6.ed. Porto Alegre: Artmed, 2017. 858p.

WIEN, H. C. The physiology of vegetable crops. Oxon: CABI Publishing, 1997, 672p.

Ciência Rural, v.50, n.1, 2020. 